\title{
EFEKTIVITAS IMPLEMENTASI METODE HYPNOTEACHING UNTUK MENINGKATKAN MOTIVASI DAN HASIL BELAJAR MATEMATIKA PADA SISWA SMP NEGERI
}

\author{
Hadi Kasmaja \\ Guru Matematika SMP Negeri 41 Bulukumba \\ Email : dshadikasmaja@gmail.com
}

\begin{abstract}
This study is an pre-experiment research which aims at examining (1) the implementation result of hypnoteaching method in Mathematics learning of class VII students at SMPN 41 Bulukumba, (2) the learning motivation of class VII students at SMPN 41 Bulukumba before and after being taught using hypnoteaching method, and (3) the extend of improvement of students' learning result of class VII at SMPN 41 Bulukumba taught by using hypnoteaching method. The population of the study was all class VII students at SMPN 41 Bulukumba. The sample was class VIIb students at SMPN 41 Bulukumba. Based on the effectiveness level criteria, the hypnoteaching method learning was adequately effective to be implemented on rectangular subject. It was proved by the students' learning result of class VII at SMPN 41 Bulukumba before implementing hypnoteaching method which achieved the mean score 40.24 and was in incomplete category; whereas after being taught by using hypnoteaching method, it achieved the mean score 76.59 that approximately $75 \%$ students had fulfilled minimal completeness criteria so it achieved classical completeness with fair category. The result of the study showed that the implementation of learning using hypnoteaching method for six sessions was in the category of completely implemented with the mean score 3.6. There was improvement of learning motivation of students after being taught by using hypnoteaching method from the mean score 95.96 improved to 112. There was improvement of Mathematics learning result of students in class VII at SMPN 41 Bulukumba after being taungt by using hypnoteaching method with the improvement of students' learning result counted using normalized gain formula by 0.61 .
\end{abstract}

Keywords : effectiveness, hypnoteaching, learning motivation, $N$-gain

\begin{abstract}
ABSTRAK
Jenis penelitian ini adalah penelitian pre-eksperimen yang bertujuan untuk: (1) Mengetahui hasil implementasi metode hypnoteaching dalam pembelajaran matematika pada siswa kelas VII SMP Negeri 41 Bulukumba, (2) Mengetahui motivasi belajar siswa kelas VII SMP Negeri 41 Bulukumba sebelum dan setelah diajar dengan menggunakan metode hypnoteaching, (3) Mengetahui seberapa besar peningkatan hasil belajar siswa kelas VII SMP Negeri 41 Bulukumba yang diajar dengan menggunakan metode hypnoteaching. Populasi penelitian adalah seluruh siswa kelas VII SMP Negeri 41 Bulukumba dan sampelnya adalah siswa kelas VII $I_{b}$ SMP Negeri 41 Bulukumba.Berdasarkan kriteria tingkat keefektifan, pembelajaran metode hypnoteaching cukup efektif untuk diterapkan pada pokok bahasan bangun datar segiempat. Hal ini ditunjukkan dengan hasil belajar siswa kelas VII SMP Negeri 41 Bulukumba sebelum diterapkan metode hypnoteaching mencapai skor rata-rata 40,24 dan berada pada kategori tidak tuntas. Sedangkan setelah diajar dengan pembelajaran metode hypnoteaching mencapai skor rata-rata 76,59 dan memenuhi kriteria ketuntasan minimal (KKM) sehingga mencapai ketuntasan klasikal dengan kategori sedang. Hasil penelitian menunjukkan bahwa keterlaksanaan pembelajaran dengan metode hypnoteaching selama 6 kali pertemuan termasuk dalam kategori terlaksana keseluruhan dengan rata-rata 3,6. Terjadi peningkatan motivasi belajar siswa setelah diajar dengan
\end{abstract}




\begin{abstract}
menggunakan metode hypnoteaching, dari skor rata-rata 95,96 menjadi 112. Terjadi peningkatan hasil belajar matematika pada siswa kelas VII SMP Negeri 41 Bulukumba setelah diajar dengang menggunakan metode Hypnoteaching dengan peningkatan hasil belajar siswa yang dihitung dengan rumus gain ternormalisasi sebesar 0,61.
\end{abstract}

Kata kunci : Efektivitas, hypnoteaching, motivasi belajar, N-Gain.

\section{PENDAHULUAN}

Pendidikan merupakan sesuatu yang penting dan mutlak harus dipenuhi dalam rangka upaya peningkatan taraf hidup masyarakat. Dari pendidikan inilah diperoleh pengetahuan, keterampilan serta terwujudnya sikap dan tingkah laku dalam kehidupan sehari-hari.

Dunia pendidikan memungkinkan terjadinya berbagai interaksi antara satu dengan yang lain. Baik interaksi antara pendidik dan peserta didik, pendidik dan pendidik lain serta peserta didik dan peserta didik lain. Dari berbagai bentuk interaksi, khususnya mengenai interaksi yang disengaja, ada istilah interaksi edukatif. Interaksi edukatif ini adalah interaksi yang berlangsung dalam suatu ikatan untuk tujuan pendidikan dan pengajaran. Oleh karena itu interaksi edukatif ini perlu dibedakan dari bentuk interaksi yang lain. Dalam pengertian yang lebih spesifik pada bidang pengajaran, dikenal adanya istilah interaksi belajar mengajar. Dengan kata lain apa yang dinamakan interaksi edukatif, secara khusus adalah sebagai interaksi belajar mengajar. Interaksi belajar mengajar mengandung suatu arti adanya kegiatan interaksi dari tenaga pengajar yang melaksanakan tugas mengajar disatu pihak, dengan warga belajar (siswa, anak didik/subjek belajar) yang sedang melaksanakan kegiatan belajar dipihak lain (Sardiman : $2010: 1$ ).

Sehingga yang menentukan kualitas SDM siswa adalah guru itu sendiri. Mengingat pentingnya peran guru tersebut, maka guru sebagai tenaga profesional dituntut untuk meningkatkan profesionalismenya terutama dalam penyampaian pelajaran. Pentransferan ilmu dari guru ke siswa harus dapat dipahami siswa dan mereka harus diberi kesempatan yang lebih banyak untuk mengungkapkan pendapatnya. Hal ini perlu dilakukan terutama dalam penyampaian materi pelajaran matematika sebab kebanyakan siswa menganggap matematika sebagai mata pelajaran yang sulit. Sejauh ini kegiatan pembelajaran matematika yang berlangsung di lembaga-lembaga pendidikan formal didominasi pandangan bahwa pengetahuan matematika sebagai seperangkat fakta-fakta yang harus dihapalkan, kelas berfokus pada guru sebagai sumber pengetahuan. Pembelajaran matematika yang berorientasi pada target penguasaan materi tersebut, mungkin terbukti berhasil dalam kompetensi mengingat jangka pendek, tetapi gagal dalam membekali siswa untuk memecahkan persoalan dalam kehidupan jangka panjang. Belajar matematika dirasakan sebagai tekanan dan beban, yang sering terjadi adalah materi yang telah dipelajari mudah dilupakan dan tidak bermakna bagi siswa. Akibatnya semakin tinggi jenjang pendidikan semakin tinggi materi pembelajaran matematika, semakin susah pula bagi siswa untuk memahami matematika.

Penguasaan matematika secara baik sejak dini perlu ditanamkan sehingga konsepkonsep dasar Matematika dapat diterapkan dengan tepat dalam kehidupan sehari-hari. Dengan memakai konsep dasar Matematika siswa akan memiliki bekal untuk menguak perkembangan ilmu dan teknologi yang berkembang pesat dewasa ini. Dalam pembelajaran Matematika tentunya tidak lepas dari ciri matematika itu sendiri (Depdiknas, 2006), yaitu (1) memiliki objek kejadian yang abstrak dan (2) berpola pikir deduktif dan konsisten. Disamping itu Matematika berfungsi untuk mengembangkan kemampuan berkomunikasi dengan menggunakan bilangan dan simbol-simbol serta ketajaman penalaran yang dapat membantu memperjelas dan menyelesaikan permasalahan dalam kehidupan sehari-hari.

Susanto (2013 : 185) menyatakan bahwa Matematika merupakan salah satu disiplin ilmu yang dapat meningkatkan kemampuan berpikir dan beragumentasi, memberikan kontribusi dalam penyelesaian masalah sehari-hari dan dalam dunia kerja. Menurutnya minat siswa dalam mempelajari matematika dapat disebabkan karena kurangnya pengetahuan siswa serta peran guru dalam pembelajaran yang dapat menjadikan pembelajaran matematika menjadi terasa lebih 
menyenangkan. Dari faktor-faktor tersebutlah diperlukan suatu langkah lanjut ataupun upaya dalam rangka meningkatkan mutu pendidikan dan pembelajaran yaitu dengan memilih metode pembelajaran yang inovatif agar diperoleh peningkatan hasil belajar matematika. Misalnya guru membimbing siswa untuk bersama-sama terlibat aktif dalam pembelajaran , memberikan masalah yang menarik sesuai dengan kondisi lingkungan sekitar siswa serta kemampuan siswa dan mampu membantu siswa berkembang.

$$
\text { Guru perlu mengkondisikan }
$$

pembelajaran matematika yang menyenangkan, tidak kaku, serta memperbanyak interaksi siswa dengan guru. Kondisi seperti ini membuat siswa merasa nyaman dan rileks dalam belajar sehingga pada akhirnya bisa memahami pelajaran. Salah satu caranya adalah dengan memberi sugesti-sugesti positif kepada siswa melalui pemanfaatan metode Hypnoteaching.

Hypnoteaching ini merupakan metode pembelajaran yang kreatif, unik, sekaligus imajinatif. hypnoteaching merupakan perpaduan dari dua kata, yaitu hypnosis dan teaching. Hipnosis berarti mensugesti dan teaching yang berarti mengajar. Jadi dapat dikatakan bahwa Hypnoteaching adalah usaha untuk menghipnosis atau mensugesti siswa supaya menjadi lebih baik dan prestasinya meningkat. Hypnoteaching bisa dikatakan sebagai improvisasi dari sebuah pembelajaran.

Navis (2013 : 128) mengungkapkan bahwa Hypnoteaching merupakan perpaduan pembelajaran yang melibatkan pikiran sadar dan bawah sadar. Hal ini sejalan dengan pendapat Gunawan (2007 : 18) yang mengatakan bahwa Hypnoteaching adalah metode pembelajaran yang menyajikan materi pelajaran dengan menggunakan bahasa-bahasa bawah sadar, karena alam bawah sadar lebih besar dominasinya terhadap cara kerja otak. Peran dan pengaruh pikiran sadar (conscious) terhadap diri kita adalah sebesar $12 \%$, sedangkan pikiran bawah sadar (subconscious) sebesar 88\%. Pikiran sadar dan pikiran bawah sadar saling mempengaruhi dan bekerja dengan kecepatan yang tinggi.

Menurut Yustisia (2012 : 79) ada beberapa manfaat yang bisa dicapai melalui penerapan Hypnoteaching dalam pembelajaran di dalam kelas sebagai berikut. (1) Pembelajaran menjadi menyenangkan dan lebih mengasyikkan bagi siswa, maupun bagi guru. (2) Pembelajaran dapat menarik perhatian siswa melalui berbagai kreasi permainan yang diterapkan oleh guru. (3) Guru menjadi lebih mampu dalam mengelola emosinya. (4) Pembelajaran dapat menumbuhkan hubungan yang harmonis antara guru dan siswa. (5) Guru dapat mengatasi siswa yang mempunyai kesulitan belajar melalui pendekatan personal. (6) Guru dapat menumbuhkan semangat siswa dalam belajar melalui permainan hypnoteaching. (7) Guru ikut membantu siswa dalam menghilangkan kebiasaan-kebiasaan buruk yang mereka miliki.

Penerapan metode hipnoteaching dalam pembelajaran matematika dapat menciptakan suasana pembelajaran yang efektif dan menyenangkan bagi siswa. Pembelajaran matematika tidak akan menyebabkan siswa tertekan, perasaan cemas dan takut siswa akan masalah yang diberikan dilebur oleh guru dengan sugesti-sugesti positif yang persuasif. Hypnoteaching membuat hubungan yang terjalin antara guru dengan siswa menjadi kompak dan dinamis sehingga proses belajar mengajar di kelas menjadi lebih hidup dan efektif. Matematika akan menarik perhatian siswa dan guru matematika pun mendapatkan tempat di hati siswanya.

Hypnoteaching akan menarik dan menumbuhkembangkan keinginan siswa dalam menyelesaikan persoalan yang terjadi baik di dalam pembelajaran maupun di luar konteks pembelajaran itu sendiri. Seperti yang telah menjadi harapan semua stakeholder pendidikan bahwa belajar bukan hanya sekedar menerima informasi, melainkan adanya perubahan prilaku dan tindakan yang dilakukan di dalam semua aspek kehidupan itu sendiri.

Belajar dari hasil penelitian yang telah dilakukan Ja'faruddin (2010) tentang penerapan Unconscious Mind Program (UMP) dalam pembelajaran matematika bahwa pelajaran matematika yang berorientasi pada model pembelajaran UMP akan memliki tingkat prestasi dan motivasi belajar yang tinggi jika dibandingkan dengan pembelajaran matematika melalui pendekatan konvensional.

Berdasarkan uraian masalah yang telah diuraikan diatas, penulis mengajukan penelitian yang berjudul : "Efektivitas implementasi metode hypnoteaching untuk meningkatkan motivasi dan hasil belajar matematika pada siswa kelas VII SMPN 41 Bulukumba". 
Matematika merupakan ilmu yang memiliki interprestasi yang demikian beragam. Oleh karena itu matematika yang diajarkan di sekolah juga merupakan bagian dari matematika, maka berbagai karakteristik dan interprestasi matematika dari berbagai sudut pandang juga memainkan peranan dalam pembelajaran matematika di sekolah. Dengan memahami karakter matematika, guru diharapkan dapat mengambil sikap yang tepat dalam pembelajaran matematika. Lebih jauh lagi, ia seharusnya memahami batasan sifat dari matematika yang dibelajarkan kepada anak didik. Jangan sampai guru memandang matematika hanya sebagai kumpulan rumus belaka, tidak pula hanya sebagai proses berpikir saja. Pemahaman yang komprehensif tentang matematika akan memungkinkan guru menyelenggarakan pembelajaran dengan lebih baik.

Hakikat matematika dapat kita pahami kita dengan memerhatikan pengertian istilah matematika dan beberapa deskripsi yang diuraikan para ahli berikut : Diantaranya, Romberg (1992 : 750) mengarahkan hasil penelaahannya tentang matematika kepada tiga sasaran utama. Pertama, para sosiolog, psikolog, pelaksana administrasi sekolah, dan penyusunan kurikulum memandang bahwa matematika merupakan ilmu yang statis dan disiplin ketat. Kedua selama kurun waktu dua dekade terakhir ini, matematika dipandang sebagai suatu usaha atau kajian ulang terhadap matematika itu sendiri. Kajian tersebut berkaitan dengan apa matematika itu ? Bagaimana cara kerja matematikawan ? Dan bagaimana mempopulerkan matematika ? selain itu, ketiga matematika juga dipandang sebagai suatu bahasa, struktur logika, batang tubuh dari bilangan dan ruang, rangkaian metode untuk menarik kesimpulan, esensi ilmu terhadap dunia fisik, dan sebagai aktivitas intelektual.

Pengertian yang lebih plural tentang matematika dikemukakan oleh Freudental (1991 : 1), dia mengatakan bahwa mathematics look like a plural as it still is in French Les Mathematiques. Indeed, long ago it meant a plural: four arts (liberal ones worth being pursued by free men). Mathematics was the quadrivium, the sum of arithmetic, geometry, astronomy, and music, held in higher esteem than the (more trivial) trivium : grammar, rhetoric and dialectic. As far as I am familiar with languages, Dutch is the only one in which the term for mathematics is neither derived from nor resembles the internationally sanctioned Mathematica. The Dutch term was virtually coined by simon (1548-1620): Wiskunde, the science of what is certain. Wis en zeker, sure and certain, is that which does not yield to any doubt, and kunde means, knowledge, theory.

Dari sisi abstraksi matematika, Newman dalam Jackson (1992:755) melihat tiga ciri utama matematika, yaitu : 1) matematika disajikan dalam pola yang lebih ketat, 2) matematika berkembang dan digunakan luas daripada ilmuilmu lain, dan 3) matematika lebih terkonsentrasi pada konsep.

Sedangkan matematika dalam sudut pandang Nasution (1982 : 12) istilah matematika berasal dari kata Yunani, mathein atau manthenein yang berarti mempelajari. Kata ini memiliki hubungan yang erat dengan kata Sanskerta, medha atau widya yang memiliki arti kepandaian, ketahuan, atau inteligensia. Dalam bahasa belanda, matematika disebut dengan kata wiskunde yang berarti ilmu tentang belajar (hal ini sesuai dengan kata mathein pada matematika. Sedangkan orang Arab menyebut matematika dengan 'ilmu al-hisab' yang berarti ilmu hitung. Di indonesia, matematika disebut dengan ilmu pasti dan ilmu hitung.

Matematika secara umum ditegaskan sebagai penelitian pola dari struktur, perubahan, dan ruang; tak lebih resmi, orang mungkin mengatakan bahwa matematika adalah penelitian bilangan dan angka. Dalam pandangan formalis, matematika adalah pemeriksaan aksioma yang menegaskan struktur abstrak menggunakan logika simbolik dan notasi matematika.

Dari beberapa penjelasan di atas dapat disimpulkan bahwa pembelajaran matematika adalah proses interaksi antara guru dan siswa yang melibatkan pengembangan pola berfikir dan mengolah logika pada suatu lingkungan belajar yang sengaja diciptakan oleh guru dengan berbagai metode agar program belajar matematika tumbuh dan berkembang secara optimal dan siswa dapat melakukan kegiatan belajar secara efektif dan efisien.

Hypnoteaching merupakan improvisasi dari sebuah metode pembelajaran dan pendidikan. Hypnoteaching mencoba hadir dengan menyuguhkan sebuah pendekatan konseptual baru dalam bidang pendidikan, pembinaan dan sekaligus "pencerahan dan pengobatan" pada para siswa yang bermasalah. 
Hypnoteaching merupakan perpaduan antara kedahsyatan ilmu hipnosis dengan kemuliaan ilmu pendidikan.

Hypnoteaching berasal dari kata hypnosis dan teaching. Dari hal tersebut Nurcahyo (Hajar, 2011 ; 75) mengartikan bahwa hypnoteaching adalah seni berkomunikasi dengan jalan memberikan sugesti agar para siswa menjadi lebih cerdas. Sejalan dengan itu Noer juga memberikan defenisi mengenai hypnoteaching yaitu proses pengajaran yang dapat memberikan sugesti kepada siswa. Menurut Navis (2013 : 128), Hypnoteaching merupakan perpaduan pembelajaran yang melibatkan pikiran sadar dan bawah sadar.

Metode hypnoteaching juga dapat didefinisikan sebagai metode pembelajaran yang dalam menyampaikan materi, guru memakai bahasa-bahasa bawah sadar yang bisa menumbuhkan ketertarikan tersendiri kepada peserta didik (N. Yustisia,2012 : 75). Hypnoteaching ini merupakan pembelajaran yang kreatif, unik, sekaligus imajinatif. Sementara itu , menurut Noer $(2010: 21)$, dalam Hypnoteaching guru bertindak sebagai penghipnotis, sedangkan siswa berperan sebagai suyet atau orang yang dihipnotis . Dalam pembelajaran, sebenarnya guru tidak perlu menidurkan siswa ketika memberikan sugesti. Guru cukup menggunakan bahasa yang persuasive sebagai alat komunikasi yang sesuai dengan harapan siswa.

Hypnosis in teaching bekerja pada level pikiran alpha. Dalam level ini, kita mengkondisikan siswa agar masuk dalam hypnosis state (kondisi hypnosis). Dengan demikian, diharapkan setiap informasi bisa dengan mudah masuk kedalam memori jangka panjang siswa tanpa adanya distorsi atau pikiranpikiran lain yang membebaninya.

Kunci dari metode hypnoteaching sebenarnya adalah bagaimana guru bisa menciptakan lingkungan belajar yang nyaman secara intern (psikis) maupun ekstern (fisik). Karena ketika kenyamanan ada dalam pembelajaran, mereka akan merasakan pula proses belajar yang menyenangkan, dan ketika dalam sebuah pembelajaran rasa nyaman dipastikan materi yang disampaikan guru akan mudah sekali diserap oleh peserta didik. Hal itu bisa terjadi karena kondisi nyaman adalah kondisi yang diciptakan oleh operator hipnotis (guru) dengan sebuah komunikasi yang berguna membawa subjek hipnotis (peserta didik) ke kondisi alam bawah sadarnya.

Langkah-langkah hypnoteacing dalam pembelajaran matematika meliputi:

\section{Perhatian yang terpusat atau terfokus}

Kondisi hypnosis dapat dibagi menjadi hypnosis ringan (light hypnosis) dan hypnosis dalam (deep hypnosis). Proses kegiatan belajar mengajar lebih menggunakan teknik light hypnosis ketimbang deep hypnosis. Kondisi fokus saat belajar sebenarnya kondisi yang dibutuhkan oleh setiap orang agar pikiran tidak bercabang dan tingkat emosional seseorang menjadi stabil.

Seorang siswa yang sedang memperhatikan seorang guru mengajar sering mengalami gangguan konsentrasi disebabkan berbagai bentuk pikiran masih melayanglayang di benaknya. Tiba-tiba saja, materi yang sedang diajarkan oleh guru di depan kelas hilang begitu saja dari pikiran siswa, tergantikan oleh pikiran lainnya yang mungkin lebih seru atau lebih nyaman untuk dipikirkan. Oleh karena itu, teknik hipnosis diperlukan untuk mengarahkan subjekn/siswa bisa memusatkan diri terhadap hal tertentu. Hal tersebut bereaksi ditandai dengan hilangnya perasaan-perasaan negatif yang membebani.

\section{Relaksasi kondisi fisik}

Relaksasi sering dilupakan pada saat sesi pembelajaran. Padahal hal itu merupakan prasyarat seseorang untuk dapat menyerap setiap data, informasi, dan pengetahuan. Sebuah ketegangan menyebabkan seseorang sulit untuk berkonsentrasi dan hasil dari pembelajaran tidak maksimal. Itulah mengapa proses pembelajaran pada pagi hari biasanya jauh lebih menyenangkan dari pada siang hari. Pada pagi hari, tingkat relaksasi seorang murid yang masih segar bugar masih tinggi. Di sinilah peran seorang guru yang mengajar di pagi hari untuk mampu memberikan motivasi kepada murid-muridnya agar tetap semangat.

Sebuah prooses pengajaran di sekolah merupakan rangkaian kerja sama antara satu guru dan guru yang lain. Jika suasana kelas pada pagi hari sudah mengandung aura emosi antara guru dan murid, bisa dibayangkan bagaimana suasana kelas selanjutnya.

\section{Doa dan Visualisasi}


Doa merupakan kekuatan yang tak terhingga yang menyelimuti diri kita dari setiap hal negatif yang akan mendatangi diri kita. Doa mengaktifkan kekuatan yang terpendam dalam diri. Mahatma Gandhi pernah berkata bahwa kekuatan tidak datang dari kemampuan fisik, kekuatan datang dari kehendak yang tangguh. Pada saat berada pada kondisi rileks dan damai, itulah saat yang tepat bagi anda untuk berdoa. Begitupun setelah anda membimbing siswa memasuki kondisi relaksasi, pada saat itu gelombang otak mereka sudah beralih dari gelombang betha menuju alpha. Saat inilah critical area siswa menjadi kurang aktif. Kondisi ini sangat identik saat kita berdoa khusyuk. Saat seperti ini adalah saat yang tepat untuk membimbing siswa berdoa kepada Allah. Bimbinglah mereka berdoa dengan visualisasi dan afirmasi.

Visualisasi bertujuan untuk memperjelas gambaran mengenai tujuan yang dicapai siswa. Seseorang bervisualisasi menghadirkan bayangan atau gambaran mengenai impiannya dengan tujuan untuk memperjelas tujuannya. Secara singkat visualisasi bertujuan untuk memperjelas impian dengan membangkitakn motivasi dan menemukan jalan untuk mewujudkannya.

\section{Afirmasi (sugesti positif)}

Afirmasi adalah sebuah pernyataan positif yang kita tuangkan kedalam tulisan maupun pikiran bawah sadar, digunakan oleh seseorang untuk menyatakan tujuan. Afirmasi ini harus positif dan tidak bertentangan dengan belief atau kepercayaan yang ada dalam diri. Afirmasi dapat berbentuk doa yang diucapkan secara berulang-ulang yang ditanamkan ke dalam pikiran bawah sadar, sehingga tubuhpun merespon sesuai dengan yang diperintahkan.

Kalimat afirmasi dapat diberikan kepada siswa, saat mereka berada dalam kondisi trance. Pada saat tersebut bimbinglah siswa mengucapkan beberapa kalimat afirmasi. Berikut ini satu contoh scrift afirmasi (sugesti positif) untuk meningkatkan prestasi belajar (Solihuddin, 2010 : 77) : Untuk meningkatkan kecepatan belajar : "mulai sekarang dan seterusnya saya memiliki kemampuan untuk memusatkan seluruh energi guna mempertinggi kecepatan belajar, mulai sekarang dan seterusnya saya adalah anak yang luar biasa, otak saya adalah otak yang sangat cerdas, semua pelajaran masuk dengan mudah sehingga kapanpun dibutuhkan, informasi akan keluar dengan mudahnya."

Efektivitas pembelajaran terjadi bila siswa secara aktif dilibatkan dalam mengorganisasikan dan menemukan hubungan-hubungan informasi yang diberikan. Hasil aktivitas ini tidak hanya meningkatkan pemahaman dan daya serap siswa pada materi pembelajaran tetapi juga melibatkan keterampilan berpikir. Selain itu efektivitas pembelajaran menjadi ukuran keberhasilan dari suatu proses interaksi antar siswa dengan siswa maupun anatara siswa dengan guru dalam proses pembelajaran untuk mencapai tujuan pembelajaran. Efektivitas pembelajaran dapat dilihat dari aktivitas siswa selama proses berlangsung, motivasi siswa terhadap pembelajaran dan penguasaan konsep siswa.

Dari uraian tersebut, dapat disimpulkan bahwa efektivitas pembelajaran merupakan proses pembelajaran untuk mencapai hasil belajar sesuai dengan tujuan pembelajaran yang telah ditetapkan. Dengan kata lain, suatu keadaan yang menunjukkan sejauh mana hasil yang diperoleh setelah pelaksanaan proses belajar mengajar.

Dalam penelitian ini, efektivitas pembelajaran didasarkan pada dua indikator yaitu motivasi dan hasil belajar siswa setelah pelaksanaan proses pembelajaran dengan menggunakan metode hypnoteaching.

Motivasi merupakan serangkaian usaha untuk menyediakan kondisi-kondisi tertentu, sehingga seseorang mau dan ingin melakukan sesuatu, dan bila ia tidak suka, maka akan berusaha untuk meniadakan atau mengelakkan perasaan tidak suka itu. Motivasi adalah hal yang sangat utama yang harus dimiliki oleh siswa dalam belajar matematika, karena siswa yang termotivasi akan terdorong untuk belajar yang giat untuk mendapatkan prestasi belajar matematika yang maksimal.

Kata motivasi menurut Uno (2007) berasal dari kata motif yang berarti kekuatan yang terdapat dalam individu tersebut bertindak dan berbuat. Sejalan dengan uno, sardiman (2010:73) mengungkapkan motif sebagai daya upaya yang mendorong seseorang melakukan sesuatu. Motif dapat dikatakan sebagai daya penggerak dari dalam subjek untuk melakukan aktivitas-aktivitas tertentu demi mencapai suatu 
tujuan. Berawal dari kata motif itu, maka motivasi dapat diartikan sebagai daya penggerak yang telah aktif dalam diri seseorang yang menyebabkan seseorang tersebut bertindak untuk melakukan sesuatu.

Motivasi belajar dapat timbul karena dua dimensi yaitu dimensi internal dan dimensi eksternal. Dimensi internal di tunjukkan oleh indikator (1) tanggung jawab siswa dalam mengerjakan tugas, (2) melaksanakan tugas dengan target yang jelas, (3) memiliki tujuan yang jelas dan menantang, (4) ada umpan balik atas hasil belajarnya, (5) memiliki perasaan senang dalam belajar, (6) selalu berusaha mengungguli orang lain, (7) diutamakan prestasi dari apa yang dikerjakan, (8) selalu meningkatkan kemampuan diri. Dimensi eksternal mempunyai indikator (1) senang memperoleh pujian dari apa yang dikerjakan, (2) bekerja dengan harapan mendapatkan nilai yang baik, (3) bekerja dengan harapan memperoleh perhatian dari teman dan guru (Uno, $2006: 23$ ).

Hasil Belajar Matematika dalam Kamus Besar Bahasa Indonesia (2008 : 486) diartikan sebagai sesuatu yang diadakan oleh usaha. Kata hasil berarti sesuatu yang telah dicapai, dilakukan atau dikerjakan menciptakan lingkungan pembelajaran yang akan meningkatkan kerja keras untuk mencapai hasil yang baik dimulai dengan menganalisa faktorfaktor yang berkenaan dengan siswa dengan guru untuk melihat tingkat keberhasilan dan kegagalan siswa dalam suatu mata pelajaran.

$$
\text { Oemar Hamalik (2004: 81) }
$$

mengemukakan bahwa hasil belajar adalah keseluruhan kegiatan pengukuran (pengumpulan data dan informasi) pengelolaan, penafsiran dan pertimbangan untuk membuat keputusan tentang tingkat hasil belajar yang dicapai oleh siswa setelah melakukan kegiatan belajar dalam mencapai tujuan pembelajaran yang telah ditetapkan. jika dikaitkan dengan belajar matematika maka hasil belajar matematika merupakan kemampuan yang dicapai siswa dalam memahami dan menerapkan konsepkonsep matematika setelah mengikuti proses belajar mengajar matematika. Untuk mengukur tingkat keberhasilan siswa dalam belajar matematika digunakan tes sebagai alat ukurnya.

Tujuan Penelitian ini adalah (1) Untuk mengetahui hasil implementasi metode hypnoteaching dalam pembelajaran matematika pada siswa kelas VII SMP Negeri 41
Bulukumba, (2) Untuk mengetahui motivasi belajar siswa kelas VII SMP Negeri 41 Bulukumba sebelum dan setelah diajar dengan menggunakan metode hypnoteaching, (3) Untuk mengetahui seberapa besar peningkatan hasil belajar siswa kelas VII SMP Negeri 41 Bulukumba yang diajar dengan menggunakan metode hypnoteaching.

Hipotesis penelitian ini adalah (1) Terjadi peningkatan motivasi belajar siswa setelah diterapkan pembelajaran metode hypnoteacing pada siswa kelas VII SMPN 41 Bulukumba". (2) Terjadi peningkatan hasil belajar matematika siswa setelah diterapkan pembelajaran metode hypnoteacing pada siswa kelas VII SMPN 41 Bulukumba"

\section{METODE PENELITIAN}

\section{Jenis dan Desain Penelitian}

Penelitian ini adalah pre-eksperimen yang melibatkan satu kelas (One Group) sebagai kelas eksperimen.

Adapun desain penelitian eksperimen yang digunakan dalam penelitian ini adalah onegroup pretest-posttest design. Desain ini terdapat pretest untuk mengetahui keadaan awal sebelum diberi perlakuan. Setelah perlakuan diberikan pengukuran posttest dan pemberian angket siswa. Dengan demikian hasil perlakuan dapat diketahui lebih akurat, karena dapat membandingkan dengan keadaan sebelum diberi perlakuan (Sugiyono, 2009: 74).

Tabel 1. Desain Penelitian

\begin{tabular}{c|c|c|c}
\hline Kelas & $\begin{array}{c}\text { Pre } \\
\text { Test }\end{array}$ & Treatment & $\begin{array}{c}\text { Post } \\
\text { Test }\end{array}$ \\
\hline $\mathrm{K}_{\mathrm{E}}$ & $\mathrm{O}_{1}$ & $\mathrm{X}$ & $\mathrm{O}_{2}$ \\
\hline
\end{tabular}

Keterangan :

$\mathrm{O}_{1}=$ Tes awal (pre test) hasil belajar sebelum diajar dengan metode Hypnoteaching. $\mathrm{O}_{2}=$ Post Test setelah diajar dengan metode Hypnoteaching

$\mathrm{X}=$ Perlakuan dalam pembelajaran menggunakan Metode Hypnoteaching 
Variabel penelitian adalah suatu atribut, sifat, atau nilai dari objek yang mempunyai variasi tertentu yang ditetapkan oleh peneliti untuk dipelajari dan kemudian ditarik kesimpulannya.

Dalam penelitian ini terdapat dua jenis variable yaitu variabel bebas (independen) dan variabel terikat (dependen) yang dipengaruhi atau menjadi akibat karena adanya variabel bebas. Variabel bebas dalam penelitian ini adalah metode hypnoteaching, sedangkan variabel terikatnya adalah motivasi belajar dan hasil belajar.

Populasi dalam penelitian ini adalah kelas VII SMPN 41 Bulukumba tahun pelajaran 2014/2015 yang terbagi dalam 4 kelas. Rancangan sampel oleh kelas tersebut terbagi secara merata. Dengan demikian kelas yang ada diasumsikan homogen. Adapun sampel dalam penelitian ini adalah kelas $\mathrm{VII}_{\mathrm{b}}$, dengan teknik pengambilan sampel berupa cluster random sampling.

Instrumen yang digunakan dalam penelitian ini adalah tes sebagai ukuran hasil belajar matematika siswa, angket motivasi siswa terhadap pembelajaran, dan lembar observasi (pengamatan) keterlaksanaan aktivitas guru dalam menerapkan metedo hypnoteaching.

Keseluruhan prosedur penelitian dapat di klasifikasikan ke dalam 3 tahap yaitu tahap persiapan, pelaksanaan penelitian dan evaluasi, seperti berikut:

a. Persiapan

1) Mengadakan observasi di lokasi penelitian untuk menentukan 1 kelas sebagai sampel penelitian.

2) Menganalisis kurikulum umtuk melihat standar kompetensi dan kompetensi dasar, sehingga tampak materi pelajaran yang akan diajarkan.

3) Merancang dan membuat perangkat pembelajaran (RPP, buku siswa, dan LKS) sesuai dengan metode Hypnoteaching.

4) Merancang dan membuat instrumen dan alat untuk mengukur hasil belajar kognitif siswa

5) Melakukan validasi terhadap instrumen dan perangkat yang digunakan dalam penelitian.

b. Pelaksanaan

1) Melakukan tes awal untuk mengetahui kemampuan awal siswa.
2) Melakukan pembelajaran pada satu kelas yaitu kelas VII B SMPN 41 Bulukumba dengan menerapkan metode hypnoteaching.

c. Evaluasi

Evaluasi berupa posttest dilaksanakan pada akhir penelitian diluar kegiatan pembelajaran dan dirangkaikan dengan pengisian angket respon siswa.

Teknis analisis data yang digunakan adalah teknik statistik deskriptif dan statistik inferensial.

Statistik deskriptif adalah statistik yang digunakan untuk menganalisis data dengan cara mendeskripsikan atau menggambarkan data yang telah terkumpul sebagaimana adanya (Sugiyono, 2009: 147). Dalam penelitian ini, analisis deskriptif digunakan untuk mendeskripsikan hasil belajar matematika siswa, motivasi, dan keterlaksanaan pembelajaran.

Statistik inferensial adalah teknik statistik yang digunakan untuk menganalisis data sampel dan hasilnya diberlakukan untuk populasi. Teknik statistik ini dimaksudkan untuk menguji hipotesis penelitian.

Dalam pengujian hipotesis digunakan gain hasil belajar dan sebelum menguji hipotesis penelitian, dilakukan uji normalitas. Uji normalitas merupakan langkah awal dalam menganalisis data, secara spesifik uji normalitas digunakan untuk mengetahui data berdistribusi normal atau tidak. Pada penelitian ini digunakan uji one sample kolmogorov-smirnov dengan menggunakan taraf signifikansi 5\% atau 0,05, dengan syarat :

Jika $\mathrm{P}_{\text {value }} \geq 0,05$ maka distribusinya adalah normal

Jika $\mathrm{P}_{\text {value }}<0,05$ maka distribusinya adalah tidak normal

Selanjutnya hipotesis akan diuji menggunakan one sample T-Test setelah memenuhi syarat uji normalitas. Taraf signifikansi yang digunakan adalah $\alpha=0,05$. kriteria pengujiannya adalah terima Ho jika nilai $\mathrm{p}>\alpha$ dan tolak Ho jika nilai $\mathrm{p}>\alpha$. (tiro, 1999:228).

\section{HASIL DAN PEMBAHASAN}

\section{Hasil}

\section{Analisis Deskriptif}


a. Deskripsi Hasil Belajar Matematika Siswa

Pada tes hasil belajar matematika siswa baik pretest maupun posttest pada materi bangun datar segiempat secara lengkap dapat dilihat pada lampiran. Untuk lebih jelasnya hasil statistik yang berkaitan dengan skor variabel disajikan dalam tabel berikut:

Tabel 2. Nilai statistik skor hasil belajar matematika siswa

\begin{tabular}{c|c|c|c}
\hline \multirow{2}{*}{ Statistik } & \multicolumn{3}{|c}{ Nilai Statistik } \\
\cline { 2 - 4 } & Pretest & Posttest & Indeks Gain \\
\hline Ukuran Sampel & 29 & 29 & 29 \\
\hline Minimun & 27 & 69 & 0,47 \\
\hline Maksimun & 66 & 90 & 0,83 \\
\hline Mean & 40,24 & 76,59 & 0,61 \\
\hline Median & 40 & 75 & 0,61 \\
\hline Mode & 39 & 71 & 0,54 \\
\hline Standar Deviasi & 7,652 & 5,735 & 0,775 \\
\hline Variansi & 58,547 & 32,894 & 0,006 \\
\hline Range & 39 & 21 & 0,36 \\
\hline
\end{tabular}

Pada tabel 2 terlihat bahwa skor rata-rata pretest adalah 40,24 dengan standar deviasi 7,562 dan variansi 58,547. Nilai tertingginya adalah 66 dan nilai terendahnya adalah 27 , sedangkan rata-rata posttest adalah 76,59 dengan standar deviasi 5,735 dan variansi 32,894. Nilai tertingginya adalah 90 dan nilai terendahnya adalah 69. Terlihat bahwa standar deviasi dan variansi pretest lebih besar dari pada standar deviasi dan variansi post test, ini artinya data lebih beragam pada saat pretest dibandingkan dengan posttest dengan kata lain data lebih bersifat homogen pada saat posttest. Skor rata- rata peningkatan hasil belajar siswa adalah 0,61. Skor yang dicapai oleh siswa tersebar dari skor terendah 0,47 sampai dengan skor tertinggi 0,83 dengan rentang skor 0,36 . Secara deskriktif dapat dikatakan bahwa kemampuan siswa meningkat setelah implementasi metode hypnoteaching dalam pembelajaran matematika.

Berdasarkan kriteria ketuntasan minimal (KKM) yang berlaku dari SMP Negeri 41 Bulukumba yakni 70, digunakan untuk menentukan tingkat pencapaian ketuntasan hasil belajar siswa maka banyaknya siswa yang tuntas dan tidak tuntas dapat dilihat pada tabel berikut. 
Tabel 3. Distribusi Ketuntasan Hasil Belajar Siswa

\begin{tabular}{c|c|c|c|c|c}
\hline \multirow{2}{*}{$\begin{array}{c}\text { Interval } \\
\text { skor }\end{array}$} & \multirow{2}{*}{$\begin{array}{c}\text { Kategori } \\
\text { ketuntasan }\end{array}$} & \multicolumn{2}{|c|}{ Frekuensi } & \multicolumn{2}{c}{ Persentase } \\
\cline { 3 - 6 } & Pretest & Postest & Pretest & Posttest \\
\hline $0-69$ & Tidak tuntas & 29 & 1 & $100 \%$ & $3,45 \%$ \\
\hline $70-100$ & Tuntas & - & 28 & 0 & $96,55 \%$ \\
\hline
\end{tabular}

Pada tabel 2 dan 3 terlihat bahwa hasil belajar siswa setelah diajar dengan metode hypnoteaching mengalami peningkatan. Hal ini dapat dilihat dari peningkatan yang terjadi pada nilai terendah dari 27 menjadi 69, nilai tertinggi dari 66 menjadi 90. Peningkatan hasil belajar siswa juga dapat dilihat pada peningkatan presentase siswa yang mencapai ketuntasan, pada tabel 3 terlihat dari tidak ada siswa yang tuntas, setelah diajar dengan menggunakan metode hypnoteaching 96,65 \% siswa mencapai ketuntasan atau terdapat 28 siswa yang tuntas. Sementara, ketuntasan penguasaan bahan ajar matematika siswa secara klasikal tercapai bila paling sedikit $75 \%$ siswa di kelas tersebut telah tuntas. Besarnya peningkatan hasil belajar siswa yang diajar dengan metode hypnoteaching dihitung dengan lulus gain ternormalisasi dapat dilihat pada tabel berikut :

Tabel 4. Distribusi frekuensi dan persentase peningkatan hasil belajar siswa

\begin{tabular}{c|c|c|c}
\hline $\begin{array}{c}\text { Koefisien } \\
\text { normalisasi gain }\end{array}$ & Klasifikasi & Frekuensi & Presentase \\
\hline $\mathrm{g}<0,3$ & Rendah & 0 & $0 \%$ \\
\hline $0,3 \leq \mathrm{g}<0,7$ & Sedang & 26 & $89,66 \%$ \\
\hline $\mathrm{g} \geq 0,7$ & Tinggi & 3 & $10,34 \%$ \\
\hline \multicolumn{2}{c|}{ Jumlah } & 29 & $100 \%$ \\
\hline
\end{tabular}

Berdasarkan tabel 3 peningkatan hasil belajar siswa yang diajar dengan metode hypnoteaching sebagian berada dalam kategori tinggi yaitu sebanyak 3 orang dan 26 orang berada dalam kategori sedang. Berdasarkan nilai rata-rata pretest dan posttest siswa pada tabel 4 maka peningkatan hasil belajar siswa yang dihitung dengan rumus gain ternormalisasi sebesar 0,61 dan berada dalam kategori sedang.

Dari uraian diatas, dapat disimpulkan bahwa hasil belajar matematika siswa memenuhi kriteria keefektifan dengan terjawabnya hipotesis penelitian $\mathrm{H}_{1}: \mu_{\mathrm{g}}>0,5$.

\section{b. Deskripsi motivasi belajar pada pembelajaran matematika}

Berdasarkan analisi deskriptif motivasi belajar sebelum dan sesudah implementasi metode hypnoteaching, tabel dibawah ini merupakan rangkuman perbandingan dari keduanya;
Tabel 5. Rangkuman hasi analisis deskriptif skor motivasi belajar matematika sebelum dan setelah impelementasi metode hypnoteaching

\begin{tabular}{lcc}
\hline \multirow{2}{*}{ Statistik } & \multicolumn{2}{c}{ Nilai Statistik } \\
\cline { 2 - 3 } & Sebelum & Setelah \\
\hline Subjek & $\mathbf{2 9}$ & $\mathbf{2 9}$ \\
\hline Skor Ideal & $\mathbf{1 2 8}$ & $\mathbf{1 2 8}$ \\
\hline $\begin{array}{l}\text { Skor } \\
\text { Tertinggi }\end{array}$ & 121 & 127 \\
\hline $\begin{array}{l}\text { Skor } \\
\text { Terendah }\end{array}$ & $\mathbf{7 5}$ & $\mathbf{9 2}$ \\
\hline Rentang Skor & $\mathbf{4 6}$ & $\mathbf{3 5}$ \\
\hline Rata-Rata & $\mathbf{9 5 , 9 6}$ & $\mathbf{1 1 2}$ \\
\hline Varians & $\mathbf{1 2 8 , 8 9}$ & $\mathbf{1 1 6 , 4 3}$ \\
\hline $\begin{array}{l}\text { Standar } \\
\text { Deviasi }\end{array}$ & $\mathbf{1 1 , 3 5}$ & $\mathbf{1 0 , 7 9}$ \\
\hline
\end{tabular}

Dari tabel diatas terlihat bahwa sebelum penerapan metode hypnoteaching, skor motivasi terendah bernilai 75 , tertinggi 121 , dan skor rataratanya adalah 95,96. Sedangkan setelah 
implementasi metode hypnoteaching, skor terendah bernilai 92 , tertinggi 127 , dan skor rata-ratanya adalah 112. Hal ini menunjukkan bahwa implementasi metode Hypnoteaching dalam pembelajaran matematika memenuhi kriteria keefektifan karena dapat meningkatkan motivasi belajar siswa dilihat dari peningkatan setiap indikator motivasi.

\section{c. Keterlaksanaan Pembelajaran}

Keterlaksanaan pembelajaran yang diamati pada penilaian ini adalah keterlaksanaan dari rencana pembelajaran metode hypnoteaching yang terbagi atas tiga bagian utama yaitu kegiatan awal, kegiatan inti, dan kegiatan akhir. Observasi terhadap terlaksanaan pembelajaran selama 6 kali pertemuan mengacu pada 3 kategori penilaian yaitu tidak terlaksana, terlaksana sebagian, dan terlaksana keseluruhan. Berikut ini rekapitulasi skor hasil ovservasi terhadap keterlaksanaan pembelajaran dengan metode hypnoteaching;

Tabel 6. Rekapitulasi Keterlaksanaan Pembelajaran Pertemuan

\begin{tabular}{c|c|c|c|c|c|c}
\hline Aspek pengamatan & I & II & III & IV & V & VI \\
\hline Kegiatan Awal & 3,6 & 3,7 & 3,9 & 3,9 & 4 & 4 \\
\hline Kegiatan Inti & 2,9 & 3,1 & 3,5 & 3,5 & 3,6 & 3,8 \\
\hline Kegiatan Akhir & 3,3 & 3,3 & 3,7 & 3,7 & 3,7 & 4 \\
\hline Rata-rata & 3,3 & 3,4 & 3,7 & 3,7 & 3,8 & 3,9 \\
\hline
\end{tabular}

Pada aspek kegiatan awal, kegiatan inti, dan kegiatan akhir pada pertemuan awal pada pembelajaran hypnoteaching, terlihat nilai ratarata keseluruhan sebesar 3,3 yang berdasarkan kriteria keterlaksanaan yang telah ditentukan pada bab III berada pada interval $2,5 \leq \mathrm{KT}<3,5$, yang berarti untuk pertemuan awal keterlaksanaan pembelajaran hanya sebagian. Hal ini disebabkan karena belum diterapkannya beberapa langkah metode hypnoteaching dalam proses belajar mengajar. Namun secara keseluruhan untuk pertemuan selanjutnya berdasarkan kriteria keterlaksanaan yang ditetapkan pada bab III, maka keterlaksanaan pembelajaran pada kegiatan awal, kegiatan inti dan kegiatan akhir selama 6 kali pertemuan termasuk dalam kategori terlaksana keseluruhan yang berarti keterlaksanaan pada pokok bahasan bangun datar segiempat terlaksana keseluruhan dengan rata-rata 3,6 yang berdasarkan kategori keterlaksanaan berada pada $3,5 \leq \mathrm{KT}$.

\section{Analisis Infrensial}

Hasil analisa statistika inferensial dimaksudkan untuk menguji hipotesis penelitian. Sebelum melakukan analisis statistika inferensial terlebih dahulu dilakukan uji normalitas.

\section{a. Uji Normalitas}

Data yang telah diuji normalitasnya adalah nilai gain hasil belajar. Hasil perhitungan yang diperoleh untuk nilai gain hasil belajar diperoleh nilai $\mathrm{p}$-value > a yaitu $0,50>0,05$ yang berarti bahwa nilai gain hasil belajar berasal dari data yang berdistribusi normal.

\section{b. Uji Hipotesis}

Hasil uji prosyarat menunjukkan bahwa gain hasil belajar matematika menggunakan pembelajaran metode hypnoteaching berasal dari populasi yang berdistribusi normal sehingga analisis dapar dilanjutkan dengan pengujian hipotesis.

Hasil analisis SPSS untuk hasil belajar diperoleh nilai probabilitas 0,001. Karena $0,001<0,05$ maka dapat disimpulkan bahwa secara statistik $\mathrm{H}_{1}$ diterima. Hal ini berarti terjadi peningkatan hasil belajar matematika siswa setelah diterapkan pembelajaran dengan metode hypnoteaching. 


\section{Pembahasan}

Berdasarkan hasil penelitian yang telah diuraikan, maka pada bagian pembahasan hasil penelitian meliputi pembahasan hasil analisis deskriptif dan analisis infersial untuk menjawab rumusan masalah yang ada. Pembahasan meliputi : (1) Hasil Belajar matematika (2) Motivasi belajar (3) Keterlaksanaan pembelajaran, Pembahasan tersebut akan diuraikan sebagai berikut :

1. Hasil Belajar Matematika Siswa

Nilai rata-rata tes hasil belajar matematika yang diukur melalui tes awal sebelum dimulainya pembelajaran dan tes akhir setelah pembelajaran dengan menggunakan metode hyphoteaching mengalami peningkatan. Hal ini disebabkan karena siswa lebih mudah memahami materi yang diajarkan melalui contoh-contoh nyata yang dikenali siswa. Dan pembelajaran lebih bermakna karena siswa diberi kesempatan untuk mengkonstruksi sendiri pengetahuannya.

Berdasarkan hasil penelitian, ketercapaian ketuntasan belajar secara klasikal sudah tercapai yaitu $93,33 \%$ siswa dalam kelas tersebut telah tuntas atau ada 28 siswa yang mendapatkan nilai $\geq 70$. Hasil ini memberikan suatu gambaran bahwa dalam pembelajaran dengan metode hypnoteaching penguasaan matematika siswa mempunyai kecenderungan lebih baik jika diberikan masalah kontekstual dan senantiasa memberikan motivasi kepada siswa melalu proses relaksasi, anchor, visualisasi dan afirmasi.

2. Motivasi belajar

Secara umum motivasi siswa mengalami peningkatan dalam belajar matematika dengan menggunakan metode hypnoteaching. Berdasarkan hasil analisis angket motivasi secara umum siswa terlihat memiliki tanggung jawab yang tinggi dalam mengerjakan tugas, melaksanakan tugas dengan target yang jelas, memiliki tujuan yang jelas dan menantang, ada umpan balik atas hasil belajarnya, memiliki perasaan senang dalam belajar, selalu berusaha mengungguli orang lain, diutamakan prestasi dari apa yang dikerjakan,selalu meningkatkan kemampuan diri, senang memperoleh pujian dari apa yang dikerjakan, bekerja dengan harapan mendapatkan nilai yang baik, bekerja dengan harapan memperoleh perhatian dari teman dan guru.

Peningkatan motivasi belajar tersebut lahir dari sebuah proses pembelajaran menggunakan metode hypnoteaching dengan pendekatan kontekstual, dengan begitu siswa mudah memahami materi jika diberikan contoh secara kontekstual dengat mengaitkan materi dengan lingkungan sehari-hari. Hal ini sejalan dengan pendapat Gagne dan Berliner (dalam Wena, 2009) yang mengatakan bahwa motivasi belajar matematika dapat dimunculkan dengan mengaitkan materi pembelajaran dengan sesuatu yang dikenal oleh siswa, seperti aplikasi dalam kehidupan sehari-hari.

3. Keterlaksanaan pembelajaran dengan metode Hypnoteaching.

Keterlaksanaan rencana pembelajaran pada kegiatan awal, kegiatan inti dan kegiatan akhir metode hypnoteaching yang dilaksanakan selama 6 kali pertemuan pada pokok bahasan bangun datar segiempat adalah terlaksana keseluruhan dengan ratarata 3,6 , yang berdasarkan kategori keterlaksanaan berada pada 3,5 $\leq \mathrm{KT}$.

Keterlaksanaan proses pembelajaran dapat dilihat dari kegiatan yang telah dilaksanakan oleh guru dengan mengimplementasikan langkah-langkah metode hypnoteaching dalam pembelajaran matematika, Hasil implementasi tersebut terlihat pada lembar observasi keterlaksanaan pembelajaran dengan menggunakan metode Hypnoteaching

\section{SIMPULAN DAN SARAN}

Berdasarkan hasil penelitian dan pembahasan, maka kesimpulan dalam penelitian ini adalah sebagai berikut :

1. Pembelajaran metode hypnoteaching cukup efektif untuk diterapkan guna meningkatkan hasil belajar matematika pada pokok bahasan bangun datar segiempat. Hal ini dapat ditunjukkan dengan hasil belajar siswa kelas VII SMP 41 Bulukumba. Sebelum diterapkan metode hypnoteaching mencapai skor ratarata 40,867 dan berada pada kategori tidak tuntas. Sedangkan setalah diajar dengan metode hypnoteaching mencapai skor ratarata 77,067 dengan sekitar $75 \%$ siswa 
memahami kriteria ketuntasan minimal (KKM) sehingga mencapai ketuntasan klasikal dan berada pada kategori sedang.

2. Terjadi peningkatan hasil belajar siswa kelas VII SMP 41 Bulukumba setelah diajar melalui metode hypnoteaching dengan peningkatan hasil belajar siswa yang dihitung dengan rumus gain ternormalisasi sebesar 0,61 .

3. Terjadi peningkatan motivasi belajar siswa setelah implementasi metode hypnoteaching, dimana tingkat motivasi belajar matematika sebelum implementasi metode Hypnoteaching berada dalam kategori rendah dengan skor rata-rata 2,99 sedangkan setelah melalui implementasi metode Hypnoteaching berada dalam kategori sangat tinggi dengan skor ratarata 3,5 .

Berdasarkan kesimpulan penelitian ini, maka dikemukakan beberapa saran sebagai berikut :

1. Pembelajaran matematika dengan metode hypnoteaching perlu dipertimbangkan oleh guru sebagai sarana atau alternative pembelajaran untuk meningkatkan hasil belajar siswa dan motivasi siswa.

2. Bagi peneliti yang berminat mengembangkan lebih lanjut penelitian ini, diharapkan mencermati keterbatasan penelitian ini yang telah dikembangkan sehingga penelitian selanjutnya dapat menyempurnakan penelitian ini.

3. Penelitian ini selayaknya juga dilakukan pada pokok bahasan lain untuk mambantu siswa tertarik, senang dan aaktif dalam belajar matematika.

\section{DAFTAR RUJUKAN}

Depdiknas.2006. Kurikulum Tingkat Satuan Pendidikan. Jakarta : Depdiknas.

Freudental, H. 2014. Revisiting Mathematical Education. Netherlands : Kluwer Academic Punlisher.

Hajar, ibnu. 2012. Hypnoteaching : Memaksimalkan Hasil Proses Belajar Mengajar dengan Hypnoterapi. Yogyakarta : Diva Press.

Gunawan., Adi W. 2007. Hypnotherapy for Children. Jakarta : PT Gramedia Pustaka Utama
Jackson., P.W. 1992. Handbook of Research on Curriculum. New York : A Project of American Educational Research Assosiation.

Ja'faruddin. 2010. Penerapan Unconsious Mind Program (UMP) dalam Pembelajaran Matematika. Tesis. Tidak Diterbitkan. Makassar : Program Pasca Sarjana UNM

Malik, Oemar. 2004. Psikologi Belajar dan Mengajar. Jakarta : Rineka Cipta.

Nasution, Andi Hakim. 2011. Hypnosis in teaching : Cara Dahsyat Mendidik dan Mengajar. Jakarta : Visi Media.

Navis, Ali Akbar. 2013. Hypnoteaching : Revolusi Gaya Mengajar untuk Melejitkan Prestasi Siswa. Yogyakarta : Ar Ruzz Media.

Noer, Muhammad. 2010. Hypnoteaching for Success Learning. Yogyakarta : PT. Bintang Pustaka Abadi.

N. Yustisia. 2012. Hypnoteaching : Seni Mengeksplorasi Otak Peserta Didik. Yogyakarta : Ar-Ruzz Media.

Sardiman. 2010. Interaksi dan Motivasi Belajar Mengajar. Jakarta : Rajawali Pers.

Solihuddin, Ichsan. 2010. Hypnosis For Student. Bandung: Kaifa.

Sugiyono. 2009. Metode Penelitian Kuantitatif, Kualitatif, dan $R$ \& D. Bandung : Alfabeta.

Susanto, Ahmad. 2013. Teori Pembelajaran dan Pembelajaran di Sekolah Dasar. Jakarta : Kencana Prenada Media Group.

Tim Redaksi KBBI Pusat. 2008. Kamus Besar Bahasa Indonesia Pusat Bahasa. Jakarta : PT Gramedia Pustaka Utama.

Tiro, Muh Arif. 1999. Dasar-Dasar Statistika. Makassar : State University of Makassar Press.

Uno, Hamzah. 2007. Teori Motivasi dan Pengukurannya. Jakarta : Bumi Aksara. 